\title{
Is Intellectual Property the Grit IN The Wheels of INDUSTRY?
}

\author{
The Rt. Hon. Professor Sir Robin Jacob"
}

\section{A. THREe STORIES}

I begin with three stories from the past and a speech in a House of Lords debate in 1841 .

Filippo Brunelleschi was the first person in Europe to be granted a patent for an invention. He was the genius who designed and constructed the great dome of Santa Maria del Fiore, Florence's cathedral. The city fathers gave out the architectural work by a series of competitive tenders. When he tendered Brunelleschi was fearful that others would steal his ideas and get the work. So he generally tendered without saying how the job was going to be done. For instance, he was frightened about disclosing how he was going to raise the many tonnes of stone needed to create the great dome. It nearly cost him the work. By and large he was lucky in that, although he never explained how he was going to do a thing, he got the job anyway. But late in the project he was so concerned about piracy that he procured from the city fathers a patent, granted in 1421. He wanted 650 tons of a pure white marble called Bianchi Marmi for the 8 great ribs of the cupola. It was to come from a quarry at Carrara, some 65 miles away. The cheapest way to bring the marble was via the Arno, if it could be done. But the 50 miles from Pisa to Florence was most troublesome - the Arno was tideless, prone to silting and also to flooding. Brunelleschi devised some sort of barge to solve the problem. He was given a three year patent - a term which was extended at least once because the invention had not been put into use. Brunelleschi's patent does not disclose the details of his design. But informed guesses have been made. It was probably some sort of vast amphibious raft provided with giant wooden wheels to deal with shallows. We know the Florentines called it Il Badalone - 'the Monster.' Eventually Il Badalone was constructed and loaded with 100 tons of Bianchi Marmi. It set off

\footnotetext{
* Sir Hugh Laddie Chair of Intellectual Property Law. Formerly a Lord Justice of the Court of Appeal of England and Wales. This paper is based on a lecture given at Gresham College on 25 June 2002.
} 
from Pisa. It sank or became stranded less than halfway to Florence. The marble was lost. Brunelleschi's attempts to salvage it failed. I expect it is still there.

Thus the modern intellectual property system began with a flop. It has certainly moved on since then. The first British patent was more of a success. It was granted to a Dutchman, John of Utynam in 1449. He had special techniques for making stained glass windows. He was given a monopoly plus also certain tax advantages in return for which he had to make the stained glass windows of Eton College and a now defunct Cambridge College. Notably, he also had to train apprentices in the new techniques. Here is what his patent said: ${ }^{1}$

....and because the said art has never been used in England and John intends to instruct divers lieges of the king in many other arts never used in the realm beside the said art of making glass, the king retains him therefore for life at his wages and fees and grants that no liege of the king learned in such arts shall use them for a term of twenty years against the will and assent of John, under a penalty of $£ 200$, whereof two parts shall be rendered to the king and one part to John, any liege who cannot levy that sum to suffer imprisonment without delivery save by the king's special command.

I do not think history records what John's invention was. Certainly his patent did not say. I say 'invention' because, until 1977, British law treated the person who first brought an idea from abroad here as much an inventor as if he had devised it himself.

My third story is later in time - well after the early Renaissance and at the beginning of the industrial revolution. It is of the Boulton and Watt patent for a steam engine. We all know that James Watt invented the steam engine. Every schoolboy and girl knows the story of him watching the kettle lid rise and appreciating the power of steam. But the story is a distortion of the truth. Watt did not devise any engine powered by steam. He devised an improvement on the existing Newcomen engine. In that engine the cylinder was filled with steam which drove back the piston. The steam was then condensed in the cylinder. Watt realised this was wasteful. His idea was to condense the steam in a separate condenser -

\footnotetext{
${ }^{1}$ Arthur Allan Gomme, Patents of Invention: Origin and Growth of the Patent System in Britain (Longmans Green for the British Council 1946) 6.
} 
thereby, in his words 'not wasting a particle of steam'. ${ }^{2}$ He found a brilliant entrepreneur in Boulton. Their partnership exploited the patent brilliantly - not, primarily, by sales of actual engines (though they did make some parts, such as valves). What they did was to demand royalties on the basis of the savings made by using the Watt invention compared with using the Newcomen engines. Although the users of engines were saving money by the use of the Watt engine, the payment of royalties, as it often does, came to cause much resentment. It is all too easy to take an invention for granted once it has been made. One is reminded of the Burghers of Hamelin Town before and after the problem was solved:

Before:

"Will you give me a thousand guilders?"

"One? Fifty thousand - was the exclamation

Of the astonished Mayor and Corporation"

After:

"But as for the guilders, what we spoke

Of them, as you very well know, was in joke.

Besides our losses have made us thrifty.

A thousand guilders! Come take fifty."

Boulton and Watt used the law and the threat of law powerfully. They restricted use to designs of engine controlled by them. They were none too precise as to what the scope of their patent was, but made it clear that any variant was likely result in a lawsuit. They sent grim faced men from Birmingham to Cornwall to serve writs and injunctions. The Cornishmen did not take this lightly. They suspended one man who tried to serve an injunction by ropes over a mineshaft. There was a lot of litigation. Boulton and Watt largely won, but, in holding a particular machine to be piratical, Chief Justice Eyre expressed great doubt as to whether the specification was sufficient. But that did not prevent Boulton and Watt from further merciless exploitation of the patent.

\footnotetext{
${ }^{2}$ Henry W. Dickinson, James Watt: Craftsman and Engineer $\left(1^{\text {st }}\right.$ ed Cambridge University Press 2010) 38.
} 
The vice-like control of Boulton and Watt, exercised by a combination of actual and perceived, or merely forcefully claimed, rights finally went with the expiry of the patent in 1799. The control plainly hindered the development of steam engines, particularly the development of 'strong steam' engines - that is to say, high-pressure engines. Richard Trevithick was the first to realise completely that if you used high enough pressure you could do away with condensing the steam altogether. You just let it escape to atmospheric pressure. The machine 'puffed' as the steam formed clouds of water droplets. True you lost a 'particle of steam' (which you could have condensed by cooling) but that was well worth the saving. The whole engine could be small enough to be put on a carriage and drive the wheels - motor transport was born properly. Trevithick's puffers came shortly after the Watt patent went.

The piece of parliamentary debate relates to the fierce arguments in the 1840 's about the length of term of copyright. By 1840 the term was 28 years from publication or until the year of death of the author, whichever was the longer. It was thought too short. A Bill was introduced into the Commons by Sergeant Talfourd to make the term 60 years from the death of the author. Lord Macaulay opposed this vehemently in the Lords. Here is some of what he said: ${ }^{3}$

It is good that authors should be remunerated, and the least exceptionable way of remunerating them is by a monopoly. Yet monopoly is an evil. For the sake of the good we must submit to the evil: but the evil ought not to last a day longer than is necessary for the purpose of securing the good.

He went on to point out that the balance between the evil of monopoly and the good of author's remuneration shifted in favour of the evil the longer the term: ${ }^{4}$

A monopoly of sixty years produces twice as much evil as a monopoly of thirty years and thrice as much evil as a monopoly of twenty years. But it is by no means the fact that a posthumous monopoly of sixty years gives to the author thrice as much pleasure and thrice a strong a motive as a posthumous monopoly of thirty years.

\footnotetext{
${ }^{3}$ Thomas Babington Macaulay, The Miscellaneous Writings of Lord Macaulay (Longman, Green, Longman and Roberts, 1860) <http://www.fullbooks.com/TheMiscellaneous-Writings-and-Speeches-ofx31295.html $>$ accessed on 5 August 2012. ${ }^{4}$ ibid.
} 
He went to give an example. The quote is a little long, but delicious: ${ }^{5}$

Dr Johnson died fifty-six years ago. If the law were what my honourable and learned friend wishes to make it, somebody would now have the monopoly of Dr Johnson's works. Who that somebody would be it is impossible to say; but we may venture to guess. I guess, then, that it would have been some bookseller, who was the assignee of another bookseller, who was the grandson of a third bookseller, who had bought the copyright from Black Frank, the doctor's servant and residuary legatee in 1785 or 1786 . Now, would the knowledge that this copyright would exist in 1841 have been a source of gratification to Johnson? Would it have stimulated his exertions? Would it have once drawn him out of his bed before noon? Would it have cheered him in a fit of the spleen? Would it have induced him to give us one more allegory, one more life of a poet, one more imitation of Juvenal? I firmly believe not.

\section{B. The Song Remains the Same}

What can we learn from these bits of history in a modern context? Well, actually rather a lot. I start with John's patent. A major purpose of the grant of John's patent was in part the same as the purpose of a patent today, namely that disclosure of an invention should be given in return for a time-limited monopoly. John was to disclose to apprentices - the modern way is to disclose in the patent itself. By and large the system works well. Disclosure of inventions still lies at the heart of the system but a little less so than it was. Under our old law, the rule was that if you commercialised an invention, even by a single sale, prior to seeking a patent, the patent was no good - it was not novel. You could not even secretly work the invention without making any subsequent patent invalid. The common law encouraged, as far is it could, early disclosure in the trade off between incentive to invent and monopoly. Now the rule is different. Only a disclosure which enables an ordinary skilled man to work the invention invalidates. ${ }^{6}$ A product can be in all the shops, but unless you can work out how it is made, there can be a subsequent patent. The balance shifted towards monopoly - as it has in almost every aspect of intellectual property over the last 30 years, both in terms of legislation and judicial decisions, particularly, so far as the latter are concerned, in the USA.

\footnotetext{
${ }^{5}$ ibid.

${ }^{6}$ See Synthon BVv SmithKline Beecham Plc (No 2) [2006] RPC 10.
} 
Disclosure now leads to a new problem - information overload. By 2001 the European Patent Office had grown from nothing in 1977 to a staff of over $6000^{7}$ and an annual income of over $€ 1$ billion. ${ }^{8}$ In 2011 it received around 142,000 patent applications. ${ }^{9}$ Now we all know that there are many ideas which seem bright at the time but subsequently turn out to be useless or worse. That is very true of patents and patent applications. Applications are examined for novelty and inventive step. Some fail at that stage. Others are granted but for one reason or another the idea is not considered worthwhile protecting. The number of patents which are renewed by the payment of fees to the end of their maximum life, 20 years, is but a small proportion of those filed. So there are many many patent specifications out there but no one to tell you which ones are commercially important, or even which ones actually work as promised. Many patents are for ideas no better or more practical than was Brunelleschi's for Il Badalone.

It remains the case however that industry must read all patent applications relevant to its activities. It must do so to see whether anything it does or is proposing to do infringes or will do so. In that regard alone, I was told that BP estimated over half the resources of its patent department were devoted to that task. The applications must also be read to learn of new ideas - the system there serving its intended purpose - the same purpose expressed in John of Utynam's patent.

In passing it may be worth noting a second order effect, not intended in the time of Brunelleschi or John of Utynam. Important commercial monopolies create an incentive to design around them. This incentive is additional to the incentive provided by the prospect of a patent monopoly. Glaxo's Zantac (ranitidine) was at one point the top selling pharmaceutical in the world. It was the result of an inventive design around SmithKline's cimetedine patent. The incentive to design around was one of the spurs of the men of Cornwall faced with Boulton and Watt.

\footnotetext{
${ }^{7}$ European Patent Office, Annual Report 2011: Five Year Review

$<$ http://documents.epo.org/projects/babylon/eponet.nsf/0/8AA0C5EA5DB73EAEC12 579C2002B829B/\$File/Five_year_review_en.pdf $>$ accessed on 5 August 2012.

${ }^{8}$ EPO, Financial Statements, Accounting Period 2011.

$<$ http://documents.epo.org/projects/babylon/eponet.nsf/0/e0e217b1912e70ffc1257a30 004048c7/\$FILE/financial_statements_11_en.pdf $>$ accessed on 5 August 2012.

${ }^{9}$ EPO, Annual Report $201 \overline{1}$ (n 7).
} 
On any basis, therefore the patent system has a substantial 'transaction cost' - a happy phrase of economists. All patent offices, patent agents and patent lawyers are part of that transaction cost. Indeed you are reading an article by a transaction cost at this very minute. So great has been the growth of intellectual property law in the last 40 that I dare take a guess. It is that more than half of all intellectual property lawyers of the world who have ever lived are still living and probably still in active practice.

I wish to say some more about transaction costs. Intellectual property rights, unlike say rights in land, are apt to be fuzzy at the edges. For instance whether an invention is obvious, whether a word or phrase in a patent claim has a wide or narrow meaning, whether one trademark is confusingly similar to another, whether a substantial part of a copyright work has been taken, are all matters on which reasonable minds can differ. In the competitive world served by intellectual property rights attention is particularly focussed on these fuzzy edges. If you want to make something competitive with a patented product it is upon those fuzzy edges that you focus. And uncertain laws again increase transaction costs. They also increase the power of the skilful right holders - just as the uncertainty of Boulton and Watt's rights did so many years ago.

It is for that reason that I think judges should, so far as they can, strive to keep the edges of IP rights sharp. That has not always been done. I give a recent example - one where the ECJ differed from me. Under European trade mark legislation you infringe a registered trade mark if you use it, or a confusingly similar mark, for the goods for which it is registered..$^{10}$ But you also infringe if you use it, or a confusingly similar mark, for "similar goods." 11 So, if Kodak is registered for film, the registration protects the mark used for similar goods, probably, for instance, video tape but not, say, for socks. Now what I held was that the concept of 'similar goods' was independent of the nature or fame of the mark. ${ }^{12}$ The ECJ, on a reference from Germany, differed. It held that the more famous a mark the wider the ambit of 'similar goods' for which

\footnotetext{
${ }^{10}$ Council Directive 89/104 of 21 December 1988 to approximate the laws of the Member States in relating to trade marks, art 4(1)(a).

11 ibid art 4(1)(b).

${ }^{12}$ Sabel BV v Puma AG [1997] ETMR 283 (Opinion of AG Jacob).
} 
there was protection. ${ }^{13}$ This is to make a fuzzy rule fuzzier. The result has been as any trade mark practitioner will tell you, increased uncertainty and therefore cost.

\section{GRIT IN The Wheels or Hindrance to Progress?}

I turn to another area where width of IP rights has become a topic of major debate. Many are saying that the patent system here is a substantial hindrance to progress - more than a bit of grit in the wheels - something like a large lump of concrete. I refer to the so-called patenting of genes.

It has become possible to identify stretches of DNA which code for particular proteins. DNA has a double helix structure. Along each strand of the helix are points of attachment to one of four different chemical groups, A, T, G or C. As you go along the strand you can have any one of the 4 groups at each position. So you can have a code - for instance AGTCC and so on. It is now known how that code works - when the gene is switched on, as they say, it tells various chemicals in the cell to make a particular protein. So, by identifying the code you can identify the protein. And (ignoring complications) you can work backwards from the protein to the code.

The use of these techniques has enabled scientists to put copies of particular genes into bacteria (and indeed animals) so that they produce a particular protein. For instance the protein erythropoietin (epo) is made this way. Epo is an immensely valuable drug for the treatment of anaemia - it is also misused by racing cyclists, weight lifters and other athletes. What happened was this. Natural epo is present in minute traces in human urine. Vast quantities of urine were used by a man, appropriately named Dr Goldwasser, to isolate a small amount of epo. Analysis of this made it possible to work out what a bit of the genetic code - the gene for making it was. That in turn enabled scientists to find the rest of the gene, isolate it, and put it into bacteria. The bacteria are then allowed to breed, making epo, much as yeast makes alcohol.

The resulting patent has been the subject of much litigation. It was studied by our Court of Appeal and the House of Lords - precisely on the

\footnotetext{
${ }^{13}$ Case C-251/95 Sabel BV v Puma AG, and Rudolf Dassler Sport [1997] ECR I-6191 (ECJ).
} 
question of its appropriate breadth. ${ }^{14}$ Our House of Lords had to consider related question concerning the breadth of the Patent for the Hepatitis B vaccine - and held it too wide. ${ }^{15}$

The problem with these gene patents is indeed their width. For once you have isolated a gene you set about patenting it, not in the body (which is old) but when isolated or contained in some new carrier or cell. The width of such a patent is potentially enormous - it will almost certainly cover the product of any further research based on the gene.

It has also become possible to identify particular genes which are associated with particular diseases. The precise mechanism by which the gene either causes the disease (for instance Huntington's disease) or causes a predisposition to a particular disease (for instance breast cancer) remains unknown. But you can at least produce testing kits for the disposition and even, perhaps, for the disease. Just as in the time of Boulton and Watt the problem is width of monopoly and perceived width of monopoly. I take a prominent example. A company called Myriad and connected with the University of Utah has two patents on two genes known to be associated with breast cancer. The genes are called BRCA1 and 2. It is using the patents to insist upon control over the testing of patients for the gene. It is even, as I understand it, saying only it can carry out the tests. ${ }^{16}$ Moreover many scientists fear that the patents impede research into breast cancer. They may be legally wrong about that (in Europe, at least, there is a reasonable research exemption to infringement) but it is the perception that matters. Boulton and Watt's grim faced process servers from Birmingham have their modern day equivalents, sharp-suited patent lawyers from New York or London, or open-necked ones from California. They act on a global basis.

\footnotetext{
${ }^{14}$ Kirin-Amgen Inc v Transkaryotic Therapies Inc (No.2) [2002] EWCA Civ 1096 (CA); [2004] UKHL 46, [2005] 1 All ER 667 (HL).

${ }^{15}$ Biogen Inc. v Medeva Plc [1997] RPC 1.

${ }^{16}$ This has generated a great deal of litigation in the United States. At the time of writing, the Supreme Court of the United States has remanded the latest case of the Myriad patent litigation to the Court of Appeal of the Federal Circuit for further consideration in light of the case of Mayo Collaborative Services $v$ Prometheus Laboratories, Inc, 566 US (2012):

$<$ http://www.supremecourt.gov/orders/courtorders/032612zor.pdf $>$ accessed on 5 August 2012.
} 
An associated problem with gene patents is the absence of any ability to 'design around'. I observed earlier that a clear second order effect of patents is as a spur to find something different. But gene patents are not like that. Your genes are the only genes in town. This again makes one wonder whether the patent system is too powerful in this area of human endeavour.

\section{INTERNATIONAL DEVELOPMENTS}

I turn to other IP rights more generally. Before the 1960's there were just three forms of these, patent for inventions, registered design right, and registered trade marks - with the latter went passing off rights or like rights in other countries going by the name of 'unfair competition'. Each country had its own system. Now things are very different. As part of the drafting process for the Civil Procedure Rules which was to have a Part 63 'Intellectual Property' it became necessary to list out the various types of right to which the rules might apply. Here it is: $:^{17}$

Patents (whether granted by the EPO in Munich or the British Patent Office), copyright, design right (whether under our own 1988 Act or the Community Regulation), registered designs (whether granted under the British System or the forthcoming European system), registered trade marks (whether granted by the UK Registry or the Office for Harmonisation of the Internal Market in Alicante), rights in performances, rights in semiconductor topographies, plant variety rights, moral rights, database rights, rights to prevent unauthorised decrypting, and passing off.

There are other candidates too - cases about the taking of technical trade secrets and possibly Competition Act cases. This is an awful lot to try to know about if you are a lawyer. It is industry which has to pay for that knowledge.

Industry also has to pay for lawyers to know about much more than their own country's laws and procedure. This is because trade is so globalised. This has had its effect on the IP law - it too is being globalised. That is particularly apparent within the European Union. We now have European Union Trade Marks, and European Union Community Registered and unregistered Design Rights. There is an

\footnotetext{
${ }^{17}$ Civil Procedure Rules 1998, Part 63; Practice Direction 63, Intellectual Property Claims.
} 
incomplete European Patent system. Under this, laws have been harmonised, there is a central granting authority but the result of a grant is a bunch of parallel national patents which can only be litigated in national courts. The EU is pressing to create a unitary EU patent to be enforced by a new, EU court. It would be the first truly federal court of Europe. Industry, by and large, supports this - provided there is a judicial system which can be relied upon.

On a world scale there have been massive developments too. Most prominent so far is the 'Agreement on Trade-Related Aspects of Intellectual Property Rights' of $1994 .{ }^{18}$ This forms part of the WTO agreements. For practical purposes if a nation wishes to trade it has to conform to these agreements and to TRIPS. For the first time ever there are international rules requiring member states to have basic IP laws. For instance, by incorporation of the Berne Convention, TRIPS requires members to have copyright laws protecting 'literary and artistic works' for a minimum of 50 years from the end of the author's death. Such works are defined very widely by Berne, but TRIPS goes on expressly to include computer programs too. ${ }^{19}$ Some might say it thus ensures the domination throughout the world of the big software companies for the foreseeable future.

A detailed examination of TRIPS is beyond the scope of this paper. I will just say this. To require nations such as Bangladesh, upon pain of trade sanctions, to have substantial intellectual property laws and a system of enforcement of such laws is to ask for the impossible. Although TRIPS provided some leeway for compliance, that leeway is nowhere near enough. It is hardly surprising that it causes much resentment. Mark Twain's Connecticut Yankee in King Arthur's Court said that: ${ }^{20}$

a country without a patent office and good patent laws was just a crab that couldn't travel anyway but sideways or backwards.

That is not true for third world countries. They may be crab-like but it is not the absence of a patent office which is the cause. And even the

\footnotetext{
${ }^{18}$ Accessible at $<$ http://www.wto.org/english/tratop_e/trips_e/t_agm0_e.htm>.

19 TRIPS, ibid art $10(1)$.

${ }^{20}$ A Connecticut Yankee in King Arthur's Court (The World's Classics, OUP 1997)

Ch. 9, 61 .
} 
Connecticut Yankee had in mind a system of laws which encouraged local exploitation of inventions.

\section{E. ENCOURAGEMENT OF EXPLOITATION VS. RATCHETING UP}

This brings me to the other feature of TRIPS worth mentioning. Its major departure from the driving force of John of Utynam's patent. His patent was created so as to encourage exploitation within the realm. TRIPS and the modern worldwide patent system does not do that. It provides the monopoly but not the local industry to go with it. So it does not create an incentive to invest in third world countries. Again that is resented and again that is hardly surprising. There are perhaps limited exceptions in the case of medicines. And there can simply be such powerful political forces that patent laws are swept aside - as happened in the case of the antiAIDS drug patents in South Africa.

One of the features of all these developments has been what one might call the 'ratcheting up' of rights. Let me give the paradigm example. For reasons which are not clear, the Austrians and Germans, but no-one else in Europe or elsewhere had settled on a term of copyright which was 70 years from the year of death of the author. The rest of the world had, for most of the last century, had a life plus 50 year period. I have never found the justification for that period, still less the German one. The latter is supposed to have something to do with giving a reward not just to the author but his children and grandchildren on the grounds that his children somehow lost out due to the Great War. Whatever the reason, the disparity in term was seen as distorting the common market, as it did. The solution was to ratchet up all copyrights to life plus 70 years. It was done with hardly any debate at the time. No doubt so far as our Government was concerned it was worthwhile - British copyrights, what with British Pop Music and the predominance of English as an author's language, are worth proportionately more than continental copyrights. No-one cared about Joe public.

No one has justified, or could, justify this on the grounds for the encouragement of authors. It is a pity that Lord Macaulay was not around to oppose any of this. Actually, so far as I can see, no one was - not even that the extension was retrospective with only a limited exception for those who had started exploiting a work whilst it was out of copyright. 
Thus in 2002 we have had the James Joyce copyrights held to be partly in force - the Joyce estate is concerned to preserve the purity of his work. The copyrights expired at the end of 2011, 70 years of Joyce's death.

The US has followed this ratcheting up by the EU. It too extended copyright term to 70 years. Promotion of this was largely by the vested interests of Hollywood and the record industry - the inheritors of the mantles of Lord Macaulay's booksellers. The Supreme Court held the extension constitutional by a 7 to 2 majority. ${ }^{21}$

Here are another pair of cases where there is pressure to ratchet rights upwards. First from the US. The US Courts have increasingly been prepared to hold that particular types of subject matter are patentable anything under the sun made by man is the test. So, in the US, both computer programs and business methods are patentable if they are new and non-obvious. You can have a new and improved insurance policy or even, so far as I can see, method of stacking oranges on a barrow.

So far as computer programs are concerned, no one asks whether they need the patent system for their encouragement. They already have copyright. No one could say that the rate of technical improvement in that area has been slow - do we really need patents too? As for business methods, competition lies at the heart of all business. Businesses supply products or services, they do not supply themselves. It is very difficult to see the economic justification for business method patents. There is pressure from the US for the EU to have both sorts of patent - to ratchet up.

There is ratcheting up pressure the other way too. The EU has created a curious sort of right called a database right. ${ }^{22}$ Actually there are two sorts of rights in databases - a copyright and a freestanding right. The former is directed at copying from a compilation of information. The latter is directed at extraction of information from a database. The theory is easy: it costs a lot to put a database together. So copying or its use should be protected. There are substantial problems to be resolved as to the limits of these rights. But it is clear that there are few defences inside those limits - nothing like a fair use doctrine exists. The Europeans are pressing the Americans to ratchet up their law to have database rights.

${ }^{21}$ Eldred v Ashcroft, 537 U.S. 186 (2003).

${ }^{22}$ See Directive 96/9/EC of the European Parliament and of the Council of 11 March 1996 on the legal protection of databases. 
The Americans are resisting. They have judicially abandoned copyright in mere sweat and toil works such as telephone directories. ${ }^{23}$ Many in the US are alarmed at the notion of these database rights, which, if taken to their logical conclusion certainly reach into many activities which people take for granted. The problem is exacerbated by the fact that in reality database rights are perpetual - for they undergo constant revision thereby creating fresh rights. Again no one has asked Macaulay's basic question. Is the cost of the monopoly worth it?

I could go on, taking you through other rights which have been created, reinforced or extended. Why, for instance, was the term of a UK registered design extended in 1988 from 15 to 25 years? But I believe I have said enough to paint a picture of increasing and more complex IP rights on a global scale. We have moved a long way from Brunelleschi's first patent. But I rather think we have not thought many of these rights through. We have been taken with the word 'protection', which sounds good, and forgotten its obverse, 'monopoly' which sounds bad. We have in place such a complicated and expensive set of laws for intellectual property that one can see there is much grit. It is time to try to find out how much of that grit is worth it. And I suggest it is certainly time to stop putting more grit into the machine, at least until we can know more about what we have done so far.

${ }^{23}$ Feist Publications, Inc. v Rural Telephone Service Co., 499 U.S. 340 (1991). 